\title{
Scenario-modelling for the sustainable management of non-timber forest products in tropical ecosystems
}

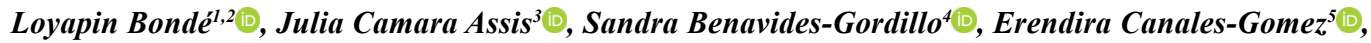

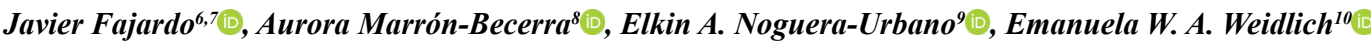

\author{
\& Judith M. Ament ${ }^{11,12 *}$ (1)
}

${ }^{1}$ Université Joseph Ki-Zerbo, Laboratory of Plant Biology and Ecology, Burkina Faso.

${ }^{2}$ West African Science Service Center on Climate Change and Adapted Land Use, Ouagadougou, Burkina Faso

${ }^{3}$ Universidade Estadual Paulista, Instituto de Biociências, Rio Claro, SP, Brasil.

${ }^{4}$ Universidade Estadual de Campinas, Instituto de Biologia, Departamento de Biologia Animal, Campinas, SP, Brasil.

${ }^{5}$ Universidad de Guadalajara,Centro Universitario de la Costa, Av. Universidad \#203, Delegación Ixtapa, C.P. 48280, Puerto Vallarta, Jalisco, México.

${ }^{6}$ UN Environment World Conservation Monitoring Centre (UNEP-WCMC), Cambridge, United Kingdom.

${ }^{7}$ Universidad Internacional Menéndez Pelayo, C. Isaac Peral 23, 28040, Madrid, Spain.

${ }^{8}$ Universidad Nacional Autónoma de México, Posgrado en Ciencias del Mar y Limnología, Ciudad de México, México.

${ }^{9}$ Instituto de Investigación de Recursos Biológicos, Alexander von Humboldt. Avenida Paseo Bolívar (Circunvalar) 16-20, Bogotá. D.C., Colombia.

${ }^{10}$ Universidade Federal de Santa Catarina, Departamento de Botânica, Florianópolis, SC, Brasil. ${ }^{11}$ Institute of Zoology, Zoological Society of London, Regent's Park, London NW1 4RY, United Kingdom. ${ }^{12}$ Centre for Biodiversity and Environment Research, University College London, Gower St, London WC1E 6BT, United Kingdom.

*Corresponding author: Judith M. Ament,e-mail: judith.ament.15@ucl.ac.uk

BONDÉ, L., ASSIS, J.C., BENAVIDES-GORDILLO, S., CANALES-GOMEZ, E., FAJARDO, J., MARRÓNBECERRA, A., NOGUERA-URBANO, E.A., WEIDLICH, E.W.A., AMENT, J.M. Scenario-modelling for the sustainable management of non-timber forest products in tropical ecosystems. Biota Neotropica 20 (suppl. 1): e20190898. https://doi.org/10.1590/1676-0611-BN-2019-0898.

\begin{abstract}
Ecosystems degradation, and consequently biodiversity loss, has severe impacts on people around the world. The Intergovernmental Platform on Biodiversity and Ecosystem Services (IPBES) is one of the international initiatives that have emerged to inform policy makers and aid decisions to prevent further global biodiversity loss, focusing on the interdependence between natural systems and human culture. IPBES promotes the use of scenarios and modelling approaches as a fundamental tool to advance the understanding of the relationships between drivers of change, Nature's Contributions to People (NCP), and social systems. Local-scale case studies with a system approach demonstrating how current knowledge can be used to inform decision-making are still scarce. Here, we present a comprehensive conceptual model and a series of four scenarios under different policies for shea tree species management, as a case-study of applying systems thinking and the NCP concept to a local-scale socio-ecological system. We first characterized the central processes, NCP, drivers and pressures affecting the shea tree system, to investigate the impacts of the multiple uses of the shea tree species on the system as a whole. We then described potential policy options, developed four scenarios, and evaluated them by a Bayesian Belief Network (BBN). We predicted qualitative outcomes of the proposed scenarios: Business-as-usual (BAU), "Conservation and fair trade", "Agroforestry and fair trade" and "Industrial development". We found that the scenarios focussing on conservation, fair trade and agroforestry, can improve the conservation status of shea trees, and enhance wellbeing in the local communities. In this case study, we demonstrate that the development of a comprehensive conceptual model at a local scale can be a useful exercise to identify opportunities for effective policy strategies and social innovation. The shea tree case study can provide an example for modelling non-timber forest products in other regions around the world that face similar drivers and pressures. Species for which this model could be adapted include Central and South American species such as the Brazilian nut (Bertholletia excelsa), cocoa (Theobroma cacao), andiroba (Carapa guianensis), açai (Euterpe oleracea) and the wax palm (Ceroxylon quindiuense). The model and workflow applied here may thus be used to understand similar socio-ecological systems with local and international economic value across the Neotropical region.
\end{abstract}

Keywords: Biodiversity and Ecosystem Services; Conceptual model; Drivers of change; Shea tree; Tropical tree species. 
Bondé, L. et al.

\title{
Modelagem de cenários para o manejo sustentável de produtos florestais não-madeireiros em ecossistemas tropicais
}

\begin{abstract}
Resumo: A degradação dos ecossistemas e sua consequente perda de biodiversidade apresentam graves impactos sobre as pessoas em todo o mundo. A Plataforma Intergovernamental de Biodiversidade e Serviços Ecossistêmicos (IPBES) é uma das iniciativas internacionais que surgiram para informar tomadores de decisão e o desenvolvimento de políticas para evitar mais perdas globais de biodiversidade, com foco na interdependência entre sistemas naturais e a cultura humana. O IPBES promove o uso de cenários futuros e abordagens de modelagem como uma ferramenta fundamental para avançar no entendimento das relações entre fatores motivadores de mudança (vetores), as Contribuições da Natureza para as Pessoas (NCP) e sistemas sociais. Estudos de caso em escala local com uma abordagem de sistemas mostrando como o conhecimento atual pode ser usado para informar a tomada de decisão ainda são poucos. Neste trabalho, apresentamos um modelo conceitual abrangente e um conjunto de quatro cenários sob diferentes políticas para o manejo da árvore de karité, como estudo de caso para a aplicação de uma abordagem de sistemas e do conceito de NCP em um sistema socioecológico em escala local. Primeiro nós caracterizamos os processos centrais, os NCP, e os vetores e pressões que afetam o sistema da árvore de karité, para então, investigar os impactos dos múltiplos usos da espécie no sistema como um todo. Em seguida, descrevemos opções de políticas possíveis, a partir das quais desenvolvemos quatro cenários e os avaliamos por Redes Bayesianas baseadas em Crenças (BBN). Nós avaliamos os resultados qualitativos dos quatro cenários de manejo propostos: "business-as-usual" (BAU), "Conservação e Fair Trade", "Agrofloresta e Fair Trade", e "Desenvolvimento Agroindustrial". Verificamos que os cenários que incluíam medidas de conservação e comércio justo, assim como o que previa práticas agroflorestais indicaram potenciais melhorias no status de conservação das árvores de karité e aprimoramento do bem-estar das comunidades locais. Neste estudo de caso, demonstramos que o desenvolvimento de um modelo conceitual mais completo na escala local pode ser útil na identificação de oportunidades para a proposição de estratégias políticas efetivas e inovação social. O estudo de caso da árvore de karité pode fornecer um exemplo de modelagem de produtos florestais não-madeireiros para outras regiões do mundo que enfrentam vetores de mudança e pressões semelhantes. As espécies para as quais esse modelo pode ser adaptado incluem espécies da América Central e do Sul, como a castanha-do-brasil (Bertholletia excelsa), cacau (Theobroma cacao), andiroba (Carapa guianensis), açaí (Euterpe oleracea) e a palma da cera (Ceroxylon quindiuense). O modelo e a proposta de trabalho aplicados aqui podem, portanto, ser usados para entender sistemas socio-ecológicos semelhantes com espécies de valor econômico local e internacional em toda a região neotropical.
\end{abstract}

Palavras-chave: Biodiversidade e Serviços Ecossistêmicos; Modelo conceitual; Vetores de mudança; Karité; Espécies de árvores tropicais.

\section{Introduction}

Increasing human activities are responsible for ecosystem degradation, overexploitation of natural resources, climate change and introductions of invasive species (Brook et al. 2008, Morris 2010), which are considered the main drivers of biodiversity and ecosystem change. The impacts of these changes also directly affect the provision of services and benefits that people obtain from ecosystems (Díaz et al. 2015). The alteration of ecosystems and the resulting reduction of biodiversity are still accelerating in many places, with severe impacts on people around the world (Ceballos et al. 2015). Savannahs and tropical rainforests are among the world's major terrestrial ecosystems, and consequently experience marked impacts from human activities (Shackleton \& Scholes 2011). Indeed, savannahs and tropical rainforest are subject to swift land-use changes due to rapid human population growth and the resulting growing interest in cash-crop production, infrastructure, grazing areas, and forest product harvesting (Wittig et al. 2007, Ouédraogo et al. 2010). The combined effects of these human pressures and climate change contribute to savannah degradation leading to biodiversity loss. Nonetheless, savannahs play enormous ecological, economic, and social roles throughout their distributional range.
For instance, they are one of the most important ecosystems providing timber and non-timber forest products (NTFPs) in the West African Sudanian region (Nacoulma et al. 2011), where local people depend on these resources for meeting daily food, energy, medicinal, and cultural needs, as well as for deriving income. Among savannah species, those of higher socio-economic importance have been found to be declining faster as a result of overexploitation and unsustainable harvesting (Wezel \& Lykke 2006).

The shea tree (Vitellaria paradoxa C. F. Gaertn.) is a tropical savannah species catalogued as threatened with extinction since 1998 (IUCN 1998). It is one of the most socio-economically and ecologically valuable species within its distribution area, providing numerous ecosystem services promoting human well-being and biodiversity conservation within the region. The shea tree is endemic to semi-arid sub-Saharan Africa and grows in 21 countries with the total number of trees estimated at 1.8 billion (Naughton et al. 2015). Growing naturally (neither planted nor cultivated), the shea tree is a "semi-domesticated" species growing in a wide variety of environments (Seghieri 2019). Farmers select and protect certain trees within their fields to benefit from the ecological and socio-economic value of the species (Elias 2012). 
Within agroecological communities, shea trees improve soil fertility of croplands and make significant contributions to climate change mitigation through their potential for carbon sequestration and water regulation (Bayala et al. 2006, Sanogo et al. 2016, Dimobe et al. 2019, Seghieri 2019). Shea tree nectar, pollen, fruit pulp and seeds are important sources of nutrition for many faunal species, including pollinator insects, birds, and mammals (Stout et al. 2018). Shea trees therefore contribute greatly to biodiversity maintenance within their distribution area. The exploitation of shea products (both for local use and industrial processing) supplements the livelihoods of more than 80 million people across the sub-Saharan Africa region (Boffa 2015, Naughton et al. 2015). For instance, in Burkina Faso the market of shea kernels and butter contributes to $12 \%$ of the total income of the poorest households (Pouliot 2012). Because shea butter is frequently used in the food and cosmetic industries, the export of shea tree products also supports the national economies of shea-producing countries with annual contributions estimated at 49 and 30 million USD in 2011 in Burkina Faso and Ghana, respectively (APFNL 2012, Hatskevich et al. 2011, Bup et al. 2014).

Despite their ecological and socio-economic importance, shea tree populations are increasingly degraded, expressed through declining tree density, low regeneration, rates and ageing of existing shea tree populations (Okullo et al. 2003, Teklehaimanot 2004, Raebild et al. 2012). The Sudanian savannah zone, for instance, reached its largest shea tree density in the 1940 s, with a population of 230 trees per ha (Chevalier 1946), but this has been reduced to 11 trees per ha on average in more recent years (Nikiema et al. 2003). This decline is mainly ascribed to (1) climate change; (2) habitat degradation due to land use change, mostly cropland expansion; (3) overexploitation of shea trees timber for firewood and charcoal production; (4) increasing international demand for shea butter, leading to high harvesting pressure on the species; (5) lack of clear policies for shea tree management; and (6) underestimation of the potential production of the species at local, national, and regional levels, as well as the associated economic opportunities (Teklehaimanot 2004, Raebild et al. 2012, Boffa 2015, Gaisberger et al. 2017, Bondé et al. 2019a). Two main sets of recommendations, based on scientific studies, have been formulated to develop sustainable strategies for the species' management.
The first suggests changes in land-use and forest policies by developing local and national markets that break the long chain of middlemen to improve farmers' income, standardizing product quality at the national level, and legalizing farmers' access to market information (Teklehaimanot 2004). The second recommends the involvement of local people in shea tree management programs to ensure the inclusion of indigenous knowledge, such as gender-specific considerations on the species' management and its particular challenges (Boffa 2015, Diarassouba et al. 2008, Elias 2015). The implementation of the above recommendations should allow shea tree restoration and population recovery, but unfortunately, recent studies based on field data and expert knowledge have shown that the species is subjected to "severe threat levels" which led it to be among the most vulnerable food species in the region (Gaisberger et al. 2017).

These findings suggest the persistence of the drivers of change in the shea tree system and potentially signals the lack of implementation of effective policies for shea tree management. Indeed, the shea sector involves many actors affecting the species (Table 1). The weakness of the system lies in the low levels of connection between actors and decisionmakers, which is one of the main constraints for the sustainable use of shea tree resources. Domestic use of shea trees as timber (for charcoal production and manufacturing of artisanal tools) is mainly connected to farmers, who are also responsible for most land use conversion from forest to croplands (Wittig et al. 2007). For the most part, men are in charge of the management of shea trees and the land, while women sell and locally process shea products. Neither of them, however, participate in decisionmaking processes such as fixing prices or developing management policies. These decisions are made at the industry-level, where exporters fix prices and ensure the quality of shea products. Lack of transparency hampers the ability of other actors and stakeholders to influence the shea market. Export data, including prices and potential of products exported by shea companies, are generally not accessible to other actors in the shea tree sector, as highlighted by Rousseau et al. (2015). Those authors indicated that many companies do not publish information on their export volumes and purchasing prices for economic reasons such as competition at the national level. This suggests that the shea sector is comparatively less well-organized than annual crop sectors such as cotton, for which purchasing prices are commonly known to producers.

Table 1. Key stakeholders in the shea sector.

\begin{tabular}{lll}
\hline Activities & Actors controlling decision making & Reference \\
\hline $\begin{array}{l}\text { Land and shea tree tenure, tree management, } \\
\text { timber harvesting }\end{array}$ & Farmers & Boffa 2015; Seghieri 2019 \\
$\begin{array}{l}\text { Fruit and nut harvesting } \\
\text { Selling and local processing of shea products }\end{array}$ & $\begin{array}{l}\text { Women and children } \\
\text { Women at both individual and association } \\
\text { level }\end{array}$ & $\begin{array}{l}\text { Elias et al. 2006; Boffa 2015; Seghieri 2019 } \\
\text { Trade system including price fixing and 2006; Boffa 2015; Seghieri 2019 } \\
\text { quality of products }\end{array}$ \\
$\begin{array}{l}\text { Knowledge generating } \\
\text { Species protection }\end{array}$ & Elias et al. 2006; Boffa 2015; Seghieri 2019 \\
& $\begin{array}{l}\text { Scientists } \\
\text { Landowners (farmers) and Government } \\
\text { (Ministry of Environment, Green Economic }\end{array}$ & Boffa 2015; Seghieri 2019 \\
& and Climate Change) & \\
\hline
\end{tabular}


Stronger connections between the various stakeholders and actors in the shea product sector are thus crucial for ensuring long-term species protection. Most studies and development activities involving the species have focused on specific aspects of the shea tree sector and have not employed a systems approach to address the sector as a whole. The development of an integrative model, linking all aspects of the shea tree social-ecological system has the potential to help understanding the system dynamics and could, therefore, be greatly beneficial in securing the sustainable use of shea tree resources as well as the ecosystems services and biodiversity values associated with the species.

The Intergovernmental Platform on Biodiversity and Ecosystem Services (IPBES) promotes the use of scenarios and modelling approaches as a fundamental tool to advance the understanding of the relationships between drivers of change and social systems to inform decisions (Díaz et al. 2015, IPBES 2016). However, case studies showing how these approaches can be operationalized at the local level to identify opportunities for policy development or social innovation at the local level (Vohland et al. 2011, Liu et al. 2015, Kok et al. 2017) are still scarce. The IPBES highlighted the importance of integrating scientific disciplines (natural sciences, social sciences, engineering), diverse stakeholders (scientific community, governments, international organizations, and civil society at different levels), and different knowledge systems (science and indigenous knowledge, local and practitioners' knowledge) on conceptual models and scenario building (Díaz et al. 2015). Even though a systemic and participatory bio-economic modelling approach was already proposed to stimulate shea parklands' production (Seghieri 2019), the relationship between drivers of change and shea tree abundance was not clearly included in the model. Here, we detail a more comprehensive, integrative, modelling approach, including both social and ecological drivers of change in shea tree abundance to investigate how social-ecological modelling can contribute to improving the management of the shea tree system.

The objectives of this paper were to: (1) develop and model scenarios based on policy development for the sustainable management of the shea tree system using a conceptual model exploring the relationships of the different social-ecological elements affecting shea tree abundance; and (2) assess the qualitative potential future outcomes of these scenarios to inform policy decisions regarding the shea tree sector.

\section{Material and Methods}

The study presented here is the result of a workshop from the São Paulo School of Advanced Science on Scenarios and Modelling on Biodiversity and Ecosystem Services to Support Human Well-Being, a course organized by the Brazilian Platform on Biodiversity and Ecosystem Services (BPBES) and funded by the São Paulo Research Foundation (FAPESP) in July 2019. We developed a conceptual model for the use of non-timber forest products under the IPBES framework (Díaz et al. 2018), using the shea tree as case study. The conceptual model was based on existing literature and discussions during the workshop. First, we described the study system, framed its products and processes as Nature's Contributions to People (NCP), and derived a conceptual model. NCP are defined as all the contributions, both positive and negative, of living nature (diversity of organisms, ecosystems, and their associated ecological and evolutionary processes) to people's quality of life (Díaz et al. 2018). Subsequently, we proposed four scenarios for the system based on selected potential management options.
Finally, we used a Bayesian Belief Network (BBN) to predict qualitative outcomes of the proposed scenarios to inform policies for the sustainable use of the shea tree.

\section{Identifying pressures and drivers and building the conceptual model}

As a first step in evaluating the shea tree socio-ecological system, we derived a conceptual model that included a focal component and the NCP it provides, four direct drivers or pressures, and three indirect drivers that modulate the intensity of those pressures (Figure 1). We selected shea tree abundance as the focal component in the system. We considered that shea abundance is a useful indicator because, (a) it has a direct relationship with shea productivity and shea use by local people, which makes it relevant to evaluate the contributions of the shea tree system to human well-being at the local level (Cissé et al. 2018), (b) it is easier to measure than alternative indicators such as tree age or fruit production. For instance, fruit production is highly variable and more difficult to estimate using the branch method (Bondé et al. 2019a). Based on literature review and discussions, we identified shea tree NCP that influence the state of the focal component of the system, and classified these into three categories: regulating, material, and non-material (Díaz et al. 2018). We also identified four different direct pressures that affect shea tree abundance. In addition to these, we recognized three main indirect drivers modulating the impact of direct pressures on shea abundance. Lastly, shea abundance, shea NCP, direct pressures and indirect drivers were integrated into a conceptual model, where elements were linked to represent how they influence each other.

\section{From conceptual model to scenario modelling}

\subsection{Scenario development}

We discussed policy options that countries within the shea tree distribution could implement and that have potential to influence shea abundance. These policies were later implemented as a set of scenarios based on alternative policy options with the potential to influence the state of shea tree abundance throughout the species distribution range (Figure 2). These scenarios were designed to present a broad overview of alternative outcome states of the system, and to investigate the likely outcomes for NCP, and human wellbeing. Scenarios illustrate how pressures and drivers can be modulated through a combination of selected policies and are useful to record the downstream effect on the system. These scenarios represent only a subset of the pool of possible scenarios and were selected for their potential contribution to illustrate the role of different policy management options over the shea tree system.

\subsection{Scenario implementation}

Modelling of outcomes of various scenarios was implemented as a Bayesian Belief Network (BBN) using the Netica software (version 3.07). BBNs are a stochastic modelling technique that uses probabilistic dependencies between components of a model as a common metric, allowing the integration of qualitative information. Netica uses the Lauritzen and Spiegelhalter algorithm (Lauritzen and Spiegelhalter 1988) to calculate binary pair-wise correlations of all possible combinations of linked variables. 


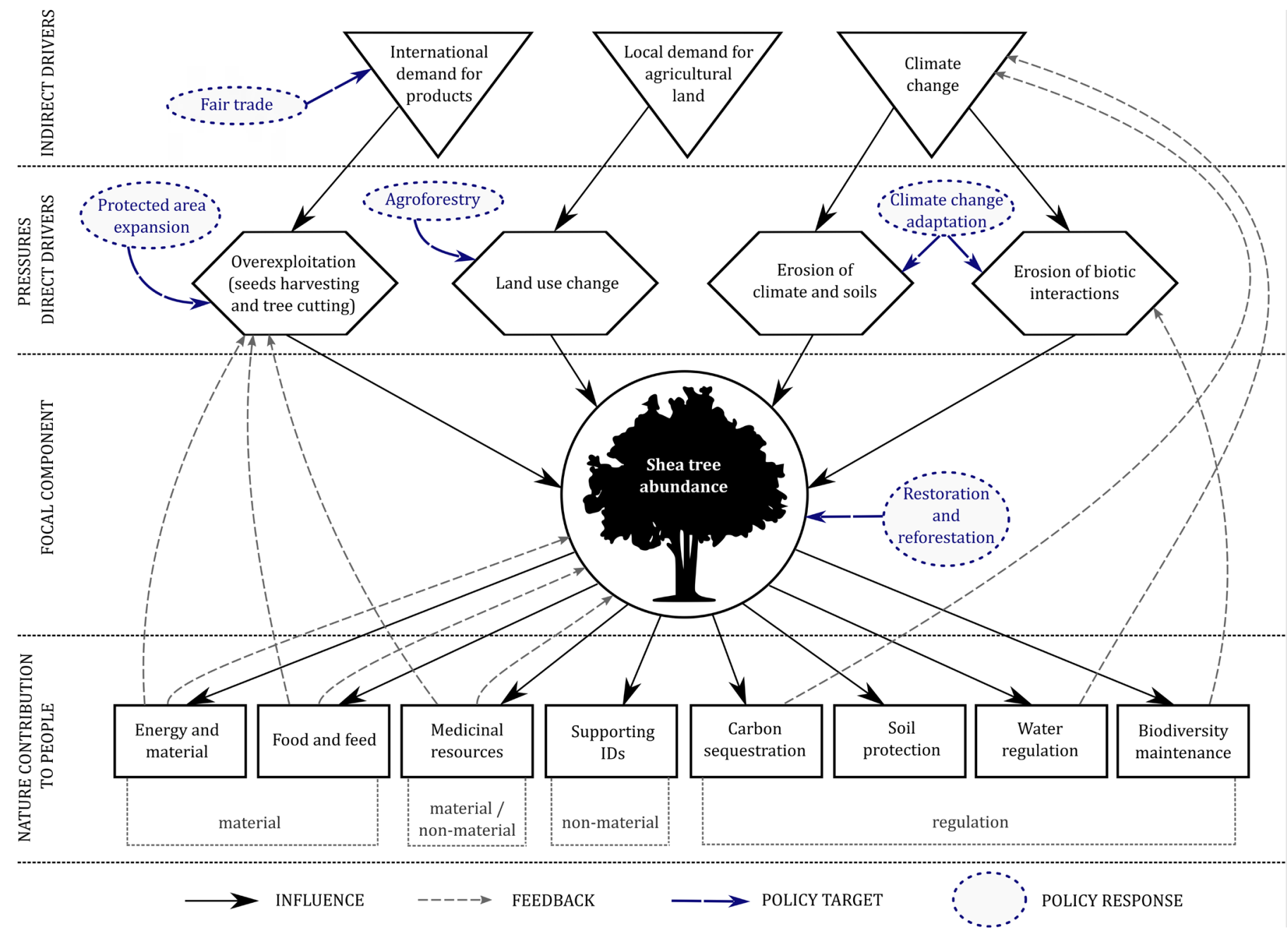

Figure 1. Conceptual model of the shea tree socio-ecological system including the focal component, drivers and Nature's Contributions to People. The relationships between system components are represented by arrows; a simple arrow implies an impact into the connected element, while a gray dashed arrow denotes a feedback relationship between the interconnected elements. Blue dashed circles illustrate the potential policies and are connected to their targets by blue dashed arrows.
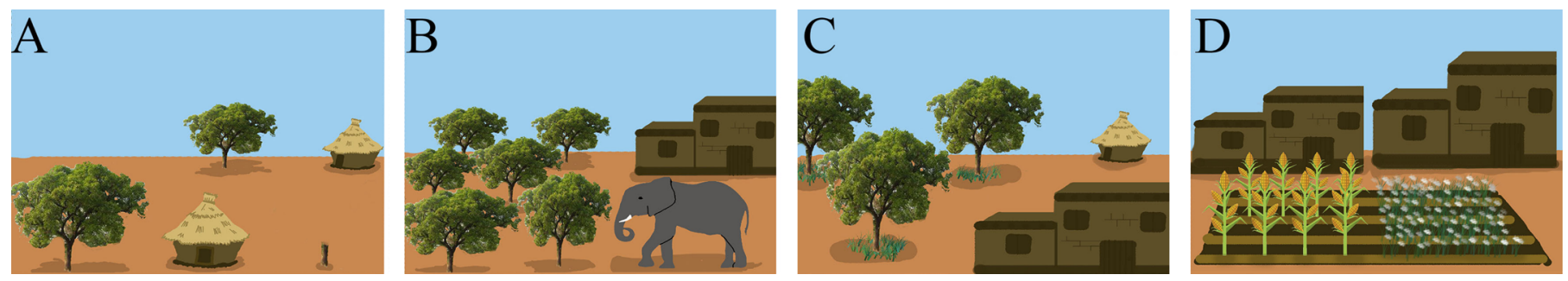

Figure 2. Visions of the four policy scenarios implemented in this paper. A) Business-as-usual, B) Conservation and fair-trade, C) Agroforestry, D) Industrial agriculture.

We used a BBN as a method of stochastic modelling to: (1) quantify the relationships between variables affecting the shea tree abundance and productivity and the potential scenario policies; (2) operationalise the model; and (3) assess the effects of alternative development pathways.

The BBN was based on the conceptual model. Each element in the conceptual model is included in the BBN as a node, and the relationships between elements were considered causal relationships represented as arcs between nodes. To reduce the complexity of the model, we did not include separate shea NCP in this exercise. Belief about variables are expressed as probability distributions that define the strength of the causal relationships.
These probabilities were defined after group discussions, and are therefore qualitative estimations based on expert criteria and existing literature (Jensen 2001).

We first defined two discrete states for each variable (i.e. "low, high"). Secondly, for each node that is affected by one or more upstream nodes, we defined a conditional probability table to express the probability for the states of the child node given the states of its parent nodes (see Tables S1-S5). To decide these probabilities, the discussion group first ordered parent nodes from lower to greater impact on the child node, and classified them as small, medium or high (section 1, Tables S1-S5). 
These impacts were identified either as positive or negative on the state of the child node. Impact order and relative magnitudes were set based on group discussions and the literature. Then, those qualitative impacts were translated into probabilities (section 2, Tables S1-S5), and these were finally used to build conditional probability tables for the node (section 3, Tables S1-S5). For instance, when a policy option is thought to have a relatively small downstream impact, the probability distribution for its two states was set to be relatively balanced (e.g. $\mathrm{P}($ high $)=0.65$ and $\mathrm{P}($ low $)=0.35)$, while for policy options with a greater potential for downstream impact, the probabilities for its two states was set to be more diverging (e.g. $\mathrm{P}($ high $)=0.80$ and $\mathrm{P}($ low $)=0.20)$.

Because policies are additive, we allowed for their impact to sum up to a $\mathrm{P}($ high) $\leq 0.95$ (in the example before, if both policies were applied simultaneously the resulting probabilities would be $\mathrm{P}($ high $)=$ 0.95 and $P($ low $)=0.05)$. Lastly, we defined the current initial status of the policy elements following a similar procedure: we first classified the level at which the policy is present across countries with shea as small, small-medium, medium, medium-large, large; and then translated these categories into unconditional probabilities (Table S6). After the BBN was characterised, we simulated the effect of the four scenarios by manipulating the marginal probability distributions of the policy elements.

\section{Results}

\section{Conceptual model}

\subsection{Shea abundance and NCP}

We compiled a comprehensive list of NCP provided by shea tree that are affected by its abundance (Table 2 and Figure 1). These contributions range from cultural uses in rituals or religion, to the consumption of fruits and nuts as food and feed, the use of the timber for energy, and as raw material for artisanal tools and construction.

Table 2. Principal nature's contributions to people (NCP) provided by shea tree.

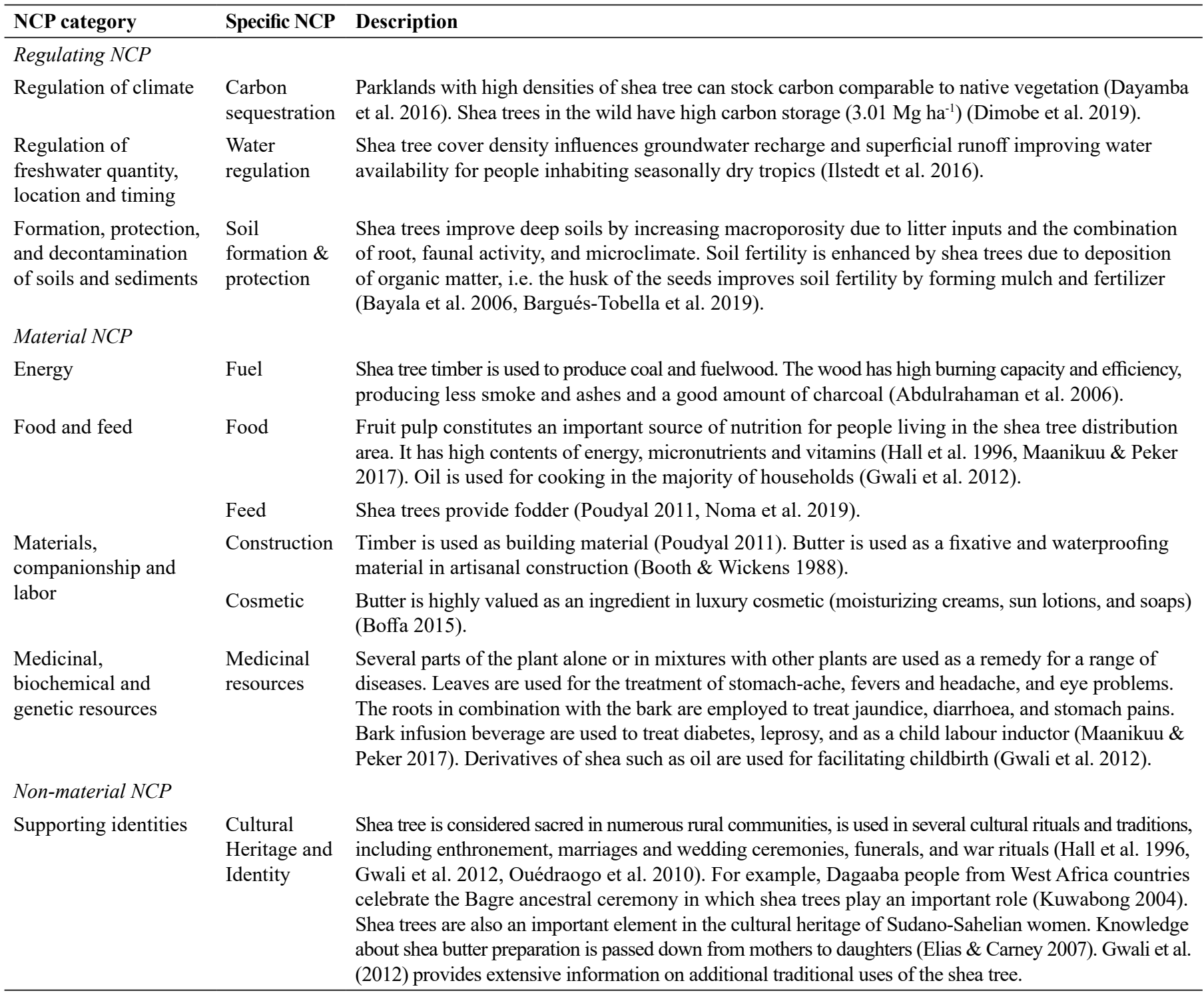




\subsection{Drivers of change and pressures}

We identified three indirect drivers (Figure 1) that influence the pressures that affect shea tree abundance, its survival and the type of NCP it provides to the local community. The first driver is climate change, which impacts biodiversity directly through effects of shifts in temperature and precipitation that affect the phenology of the tree, and its ability to grow and survive. In addition to the erosion of climate, climate change also has the potential to erode other abiotic properties of the environment of shea trees, including a role in the degradation of soils (Evans 1996). Climate change also affects the biotic interactions of the shea tree. These biotic interactions include pollinators and dispersers, which are needed to maintain shea tree production (seed production for regeneration) through effective pollination and increase the shea distribution area by seed dispersion in different habitats. They also encompass parasites and predators, which negatively affect shea tree abundance by reducing physiological and phenological events of the species, compromising seed production and their quality (especially their germinative ability). The second driver is the international demand for shea products, which influences shea tree abundance indirectly via the overexploitation of the tree and its products with economic value. This occurs through modulating local community decisions related to shea tree exploitation and land management. The third identified indirect driver of the shea tree abundance is the increasing demand for agricultural land by local communities. This driver promotes land conversion in areas previously covered by shea habitat into alternative land uses such as agriculture and urban areas. A list with indicators that can be used in the assessment of the elements of the conceptual model can be consulted in Table S7 in the Supplementary Material.

\section{Scenarios}

\subsection{Policies and scenarios}

We identified six policies with the potential to influence the drivers that have caused the current low abundance of shea tree: (1) climate change adaptation, (2) promotion of fair trade, including the development of more favourable commercialization options, (3) increasing efforts to restore and reforest shea habitat, (4) expansion of protected area networks, (5) promotion of agroforestry practices, and (6) policies towards a transition to more agro-industrial schemes. Climate change adaptation policies are those that seek to reduce the local effects of climate change on habitats and soils. Some examples of these policies include the use of nature-based solutions (NBS; Cohen-Shacham et al. 2016) to increase carbon sequestration and reduce soil degradation. Fair trade involves the arrangement of commercial practices to help producers in developing countries reach sustainable and equitable trade relationships. Despite its potential to enhance the sustainable use and trade of shea tree products by local communities, fair trade plays a small role on the trade of shea products. Restoration policies could also increase shea abundance through the direct plantation of trees and, indirectly, through the restoration of shea habitats. A similar impact could be achieved through the expansion of the protected area network, which could stop land transformation and overexploitation of shea within reserve borders. Moreover, an adequate management of protected areas could protect shea trees while permitting the sustainable use of its products by local communities.
Finally, we included two policies linked to agricultural practices that have potential to influence shea abundance. The first of them is the promotion of agroforestry practices, where cultivated shea trees are combined with shade-tolerant crops. Lastly, agriculture practices could promote industrial agricultural development based on crops such as cotton, maize, and sorghum. These practices would displace shea and cause a decline of shea habitat if they become extensive.

We grouped the above policies into four scenarios (Figure 2). The first scenario is a "business-as-usual" (BAU) scenario, depicting developments that result from the projection of the current state of the system to the future. BAU is characterized by the unsustainable use of shea tree products at the local scale. The second is the "conservation and fair-trade scenario", where policy reinforces shea tree protection via enhanced area-based conservation of the species and its assisted regeneration and reforestation, which would provide means for climate change adaptation. The previous policies are combined in this scenario with the promotion of fair-trade certification of shea products. Third, in the "agroforestry and fair-trade scenario", policy focuses on promoting local-scale agriculture through agroforestry. We included climate change adaptation in this scenario because agroforestry is often recognized as a nature-based solution to combine food production and local adaptation to changing climate. This scenario is also associated with fair trade policies, because these trades are often associated to production approaches that can be coupled with sustainable practices, such as agroforestry. Fourth, the "industrial development scenario" prioritizes the expansion of industrial agriculture in spite of seeking the maintenance of the shea tree cover.

\subsection{Scenario outcomes}

In the "BAU scenario", the BBN model shows that the unsustainable use of shea leads to a general decrease of tree abundance and tree products $\left(\mathrm{P}_{\text {abundance }}(\right.$ high $)=0.282$; Figure 3$)$. Climate change is expected to continue the erosion of the climatic and soil requirements of the shea tree $\left(\mathrm{P}_{\text {erosion of climate and soil }}(\mathrm{low})=0.77\right)$ and of its biotic interactions $\left(\mathrm{P}_{\text {biotic interactions }}(\mathrm{low})=0.68\right)$. This negative impact will be reinforced by the continued reduction of shea cover as a result of agricultural expansion $\left(\mathrm{P}_{\text {LUC }}(\right.$ high $\left.)=0.597\right)$ and, most importantly, the unsustainable exploitation of the tree and its products $\left(\mathrm{P}_{\text {overexploitation }}(\right.$ high $\left.)=0.875\right)$, which would lead to further deterioration of the provision of traditional livelihoods. For the BAU scenario, we set the state of each scenario to the current state as estimated in the discussions. For the following scenarios we increased the level of all involved upstream policies to "high".

The "conservation and fair trade scenario" depicts a future where the combination of activated policies leads to an improvement of the shea tree abundance and the NCP it provides. Specifically, the BBN projects a doubling of the probability of reaching a high shea tree abundance $\left(\mathrm{P}_{\text {abundance }}(\right.$ high $)=0.729$; Figure $\left.\mathrm{S} 1\right)$, when compared to BAU. The promotion of fair trade shea products would lead to a more sustainable harvest of shea nuts $\left(\mathrm{P}_{\text {overexploitation }}(\right.$ low $\left.)=0.95\right)$, and the subsequent development of local communities that harvest them. This, combined with better conservation policies, would lead to a recovery of natural shea tree cover $\left(\mathrm{P}_{\text {LUC }}(\right.$ high $\left.)=0.485\right)$. In this scenario, there would be an enhancement of the NCP that the shea tree provides for local communities (Table 2). 
For the "agroforestry and fair trade" scenario, the BBN indicates only a slight increase in the shea abundance $\left(\mathrm{P}_{\text {abundance }}(\right.$ high $)=0.633$; Figure S2). In this scenario, local communities' economies might benefit from the slightly increased shea abundance, products obtained from planted and managed shea trees, and also from alternative shade-tolerant crops cultivated alongside shea trees. The condition of the natural landscapes dominated by the shea tree would have the opportunity to partially recover as a result of reduced land use change $\left(\mathrm{P}_{\text {LUC }}\right.$ (high) $=0.313$ ). Changes in the use of shea products could lead to changes or losses in non-material NCP (e.g., cultural heritage and identity). However, policies only based on the promotion of agroforestry do not achieve an increasing in shea tree abundance comparable to the previous scenario, according to the BBN.

The "industrial development scenario" points to an impoverishment of shea tree ecosystems (Figure S3). These policies lead to a marked expansion of the land conversion, causing the loss of shea trees and reducing the accessibility of shea products for locals. It depicts the largest increase of land transformation $\left(\mathrm{P}_{\text {LUC }}(\right.$ high $\left.)=0.448\right)$ and decrease of shea abundance $\left(\mathrm{P}_{\text {abundance }}(\right.$ high $\left.)=0.322\right)$ of all analysed scenarios. As a result, most NCP provided by the shea tree would be reduced, including those related to cultural values of local communities (Table 2). Outcomes for all four scenarios are summarised in Table 3 and Figure 4.

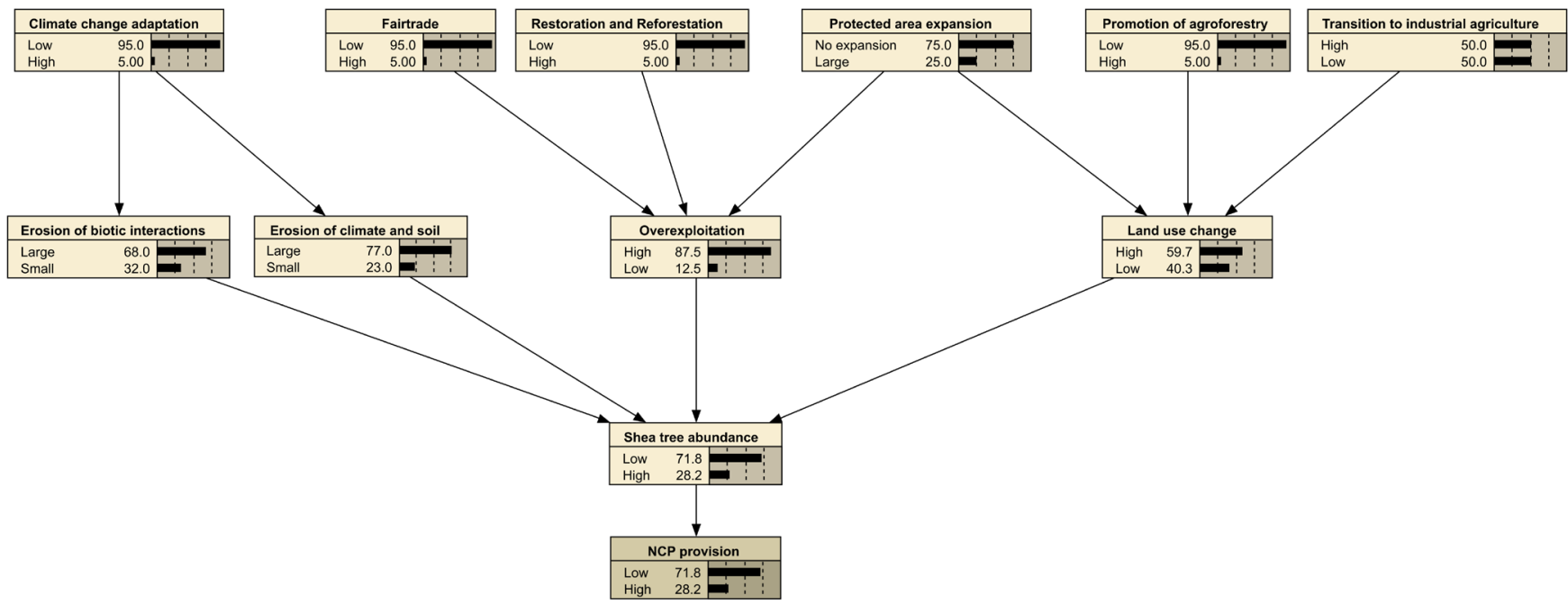

Figure 3. Bayesian Belief Network model structure of the BAU scenario. Nodes in the upper row represent policies, whereas nodes in the second row represent pressures. The probability distributions of policy nodes reflect the estimated current implementation of each policy.

Table 3. Summary of outcomes of four management scenarios for the shea tree system. Checkmarks represent the considerate policies for each scenario. The arrows are horizontal when the probabilities are distributed equally between "high" and "low" states $(\mathrm{P}=0.50 \pm 10)$. Arrows that point up have a distribution of probabilities biased towards "high" states, whereas arrows that point down have a distribution biased towards "low" states. Arrow colour indicates whether expected changes in pressures and states in each of the four scenarios can be considered positive or negative for the shea system: dark blue - strong increase; green - improvement; red - worsening. CC adaptation: Climate change adaptation.

\section{Scenarios}

\begin{tabular}{cccc}
\hline \multicolumn{4}{c}{ Scenarios } \\
\hline BAU & Conservation and fair trade & Agroforestry and fair trade $\quad$ Industrialization \\
\hline
\end{tabular}

Policies

$\begin{array}{rcc}\text { Fair trade } & - & \checkmark \\ \text { Conservation } & - & \checkmark \\ \text { Reforestation } & - & \checkmark \\ \text { CC adaptation } & - & - \\ \text { Agroforestry } & - & - \\ \text { Industrialization } & - & \end{array}$

Pressures

Overexploitation
Land use change




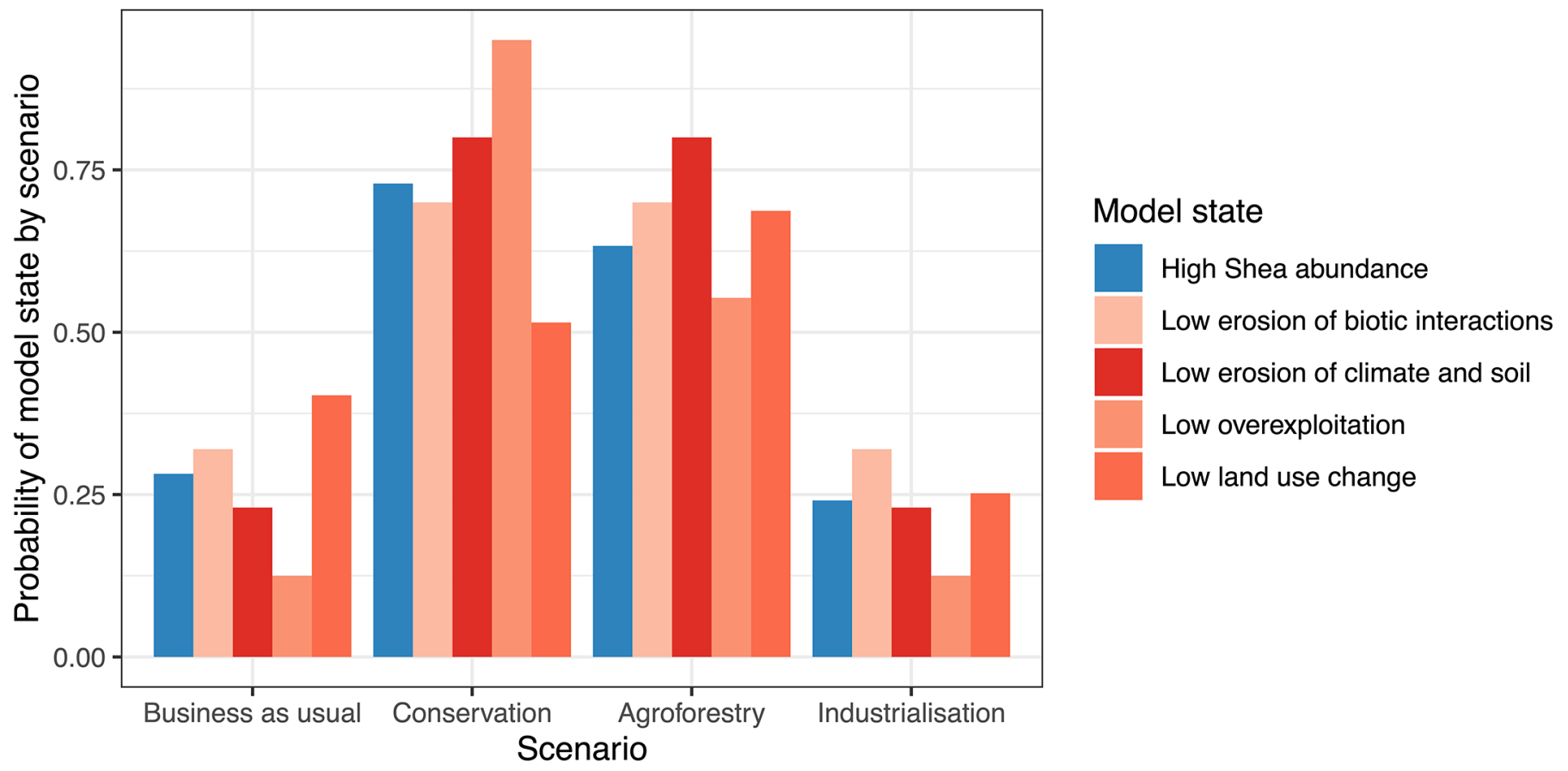

Figure 4. Summary of outcomes of four management scenarios for the shea tree system. Showing the probability that shea abundance will be high and pressures will be low in each of the four tested scenario. Note: showing $P_{a}$ (high); $\mathrm{P}$ (low); (low); $\mathrm{P}_{\mathrm{o}}$ (low); and $\mathrm{P}_{\mathrm{LUC}}$ (low).

\section{Discussion}

The shea tree provides many NCP to the local community, being a fundamental resource to their cultural, economic and social development. However, only material NCP were connected with shea tree abundance through a mutual feedback relationship. This is because the supply of these NCP is linked with extractive processes that can diminish shea tree populations. For example, the nuts are used to obtain butter to produce cosmetics and personal care products, which are traded for high profits in the international cosmetic industry. Although some material parts of the shea tree are important for the supply of nonmaterial NCPs, cultural uses of shea trees mainly exist at the local scale and are commonly associated with the implementation of traditional conservation practices (Gwali et al. 2012). Abiotic factors (such as climate variables, topography, and soil type) are other components influencing shea tree abundance, tree morphological traits and fruit yield (Lamien et al. 2008, Glèlè et al. 2011, Aleza et al. 2018, Bondé et al. 2019b). Shea tree requires specific environment characteristics such as warm temperatures $\left(24-32{ }^{\circ} \mathrm{C}\right.$ average), seasonal rainfall (600-1500 $\mathrm{mm}$ per year with a dry season period of 4 to 8 months), and elevations up to $1500 \mathrm{~m}$ (Godin \& Spensley 1971). Additionally, shea tree is not compatible with some soil types, such as highly sandy and clayish soils, areas temporarily flooded, and alluvial hollows (Boffa 2015). Abiotic factors have been used to model the potential distribution of this species under climate change scenarios (Platts et al. 2010, Naughton et al. 2015), suggesting that the species could expand its distribution range northward and southward in response to predicted climate-changeinduced increases in precipitation and temperature (Boffa 2015).

The growing demand for non-timber shea products on international markets offers an increasing source of foreign earnings to producer countries as well as an opportunity for agricultural development and the empowerment of their rural societies, especially women (Ingram et al. 2015). Therefore, international trade is an important socioeconomic driver in the shea tree system, which not only relates to fluctuating international demand and prices for shea butter (and the possible resulting overexploitation), but also to speculation on the production of mixed crops (cotton, maize, sorghum, yam, cassava) in shea tree agroforestry parks (Noma et al. 2019). This speculation can lead to agricultural intensification that requires large-scale forestclearings to create production areas, causing land-use to change and consequently affecting shea tree abundance. As described in this study, links between local actors in the shea tree system are weak, making effective conservation of the species difficult. In addition, there are gender and cultural issues that play a role at the local scale. Decisions to conserve and manage the shea tree are strongly gender dependent. Harvesting, processing and local selling of shea are locally considered as activities for women (Elias \& Carney 2007), while men are a key component in the local-scale decision-making process. Men have the final decision regarding management and conservation of the shea tree due to the fact that they are considered the landowners (Poudyal 2011). Man can choose whether to plant alternative crops as a better source of income or implement management activities to enhance shea tree nut production and income for their families (Okiror et al. 2012). Opinions of women and direct management actions, such as planting trees, are considered in some places as a usurpation of male power (Okiror et al. 2012), because planting is traditionally done by men (Boffa 2015). Besides, local population growth drives urban expansion in the shea tree distribution area, causing not only landuse change and depletion of the species, but also the transformation of livelihoods in local communities (Dapilah et al. 2018). This can also entail potential reductions in the supply of NCP by the system, particularly in the non-material category. 
Interaction with other species was identified as an important biotic factor affecting shea tree abundance. First, pollinators such as bees (Hypotrigona gribodoi (Magretti 1884) and Apis mellifera adansonii (Latreille 1804) (Stout et al. 2018) and dispersers such as flying foxes (Chiroptera: Pteropodidae) mammals (elephants, bats) (Djossa et al. 2008) and primates (Ontl 2017) were included in the model as a pressure with feedback to shea tree abundance due to their interdependence. Pollinators and dispersers play a crucial role in the species regeneration and distribution. Animal pollination is necessary in the life cycle of many plant species and play a crucial role in the long-term maintenance of biodiversity and natural ecosystems (Ratto et al. 2018), while seed dispersers significantly affect plant demography, dynamics and succession in tropical ecosystems (Petre et al. 2013). This emphasizes the need for the development of efficient strategies to ensure the conservation of pollinators and dispersers that support shea tree populations. Second, predators and parasites were linked as a pressure on shea trees because they gradually weaken the trees and can reduce nut yield. Caterpillars (Cirina forda) (Westwood 1849) and stemborers (Neoplocaedaerus sp) (N'Djolossè et al. 2012) primarily defoliate new leaves of shea trees, affecting all stages of the shea tree growth cycle, from seedlings to mature trees. Parasites like plants of the genus Tapinanthus (Boussim et al. 1993) and mistletoe (Loranthaceae) (Houehanou et al. 2011) heavily infest the trees, though at higher intensities in parklands compared to protected areas. In addition, larvae of Mussidia nigrivenella Ragonot 1888 and the Oriental fruit fly Ceratitis silvestrii Bezzi 1912 also affect mature shea trees by feeding on the pulp (Okiror et al. 2012). The biotic interactions affecting shea tree abundance are influenced by climate change. For instance, studies have suggested that climate change is one of the drivers behind the global decline of pollinators (Potts et al. 2010). However, more studies are needed to fully understand the actual impact of climate change on broader sets of species interacting on complex ecological networks. Moreover, its impact on the above described species that have a directly effect on the shea system is still largely unknown.

Our findings suggest that the integrative modelling approaches developed here can provide useful insights for non-timber forest products in other regions around the world that face similar drivers and pressures, such as low recruitment, slow growth, slow maturation, decreasing climate suitability, and high international demand. Examples of species in Central and South America that might be part of an equivalent system with similar unsustainable situation are the Brazilian nut (Bertholletia excelsa O. Berg), cocoa (Theobroma cacao L.), andiroba (Carapa guianensis Aubl.) açai (Euterpe oleracea Mart.) or the wax palm (Ceroxylon quindiuense (H. Karst)). The case of the wax palm is particularly similar to that of the shea tree, as this palm species is used not only as part of local economies but also for tourism, while also relevant for its cultural value. All these examples of plant species are to some extent threatened by land use change, fire rates, decrease of pollinators, international demand and fare exchange with local people (Bertwell et al. 2018, Porcher et al. 2018). As in the case of the shea tree, the sustainable use of these plant resources and their conservation should be sought through bold strategies that aim at addressing the different drivers that place pressure on them.

The four proposed scenarios are imagined to unfold over varying time horizons. The business-as-usual scenario might materialize over a shorter timeframe than the alternative scenarios. Following the nomenclature in Sardar and Sweeney (2016), this scenario is within the 'extended present' type of future. The conservation and fair-trade scenario is thought to be achievable within a 'familiar future' that is further into the future than BAU, but not by much.
The transformations that substantiate this scenario are extensions of policies that exist today, but which have yet to take (large-scale) effect. The last two scenarios (agroforestry and industrial development) belong to the class of 'unthought futures', which lie in the unforeseeable future. These two scenarios require large-scale transformations that can only be achieved over a long timeframe.

Through scenario-analysis, we demonstrated how a variety of policy implementations could affect the shea tree system and highlighted a few potential management strategies that could contribute towards improving the sustainable management of shea tree habitats. First, we identified actions that the local population could implement to reduce the negative effects of land use change, and one of the main drivers of shea tree abundance declines. For instance, the plantation of shade-tolerant crops and the adoption of a culture of agroforestry could help mitigate the loss of shea tree abundance. Shea and other trees improve soil fertility and contribute to mitigate climate change effects at both, local (by regulating water flows and maintaining suitable microclimatic conditions) and global scales by increasing carbon sequestration (Van Noordwijk et al. 2014). The use of shea trees in agroforestry systems would benefit from the exploration of improved domestication practices (Seghieri 2019). The implementation of land tenure policies to ensure clarity on land (and tree) ownership could be a viable additional policy to implement to reach a sustainable planning for the local demand for agricultural land (Seghieri 2019). Second, to mitigate negative impacts of overexploitation and human population growth, policies related to assisted regeneration could be an important strategy. These include the promotion of tree-planting, and the improvement of seedling care practices. However, it is important to consider that the shea tree has a low growth rate (1-6 mm/year) (Serpantié et al. 1996), and that regeneration is a difficult long-term process that requires policy support. Finally, to adapt to growing international demand and international trade, a strategy to reinforce fair-trade certification could be implemented (Greig 2006). In order to achieve a better future for local communities and promote the sustainable use of the shea tree, pragmatic policy proposals may include not only fair-trade certification but also local legislation to regulate shea nut prices and support shea tree restoration. Indeed, in the use and management of commercial non-timber forest products, people are able to concentrate their efforts on management activities that provide the highest rewards (Belcher et al. 2005). Therefore, shea tree products need to be purchased at profitable price for local communities. Finally, the scenarios screened in this study showed that no single policy option might have the potential to restore high shea abundances on its own. Instead, multidimensional scenarios that address the different indirect drivers of the system seem to be required for a substantial recovery of shea habitats. In this regard, the "conservation and fair trade scenario", which combined addressing the problems of overexploitation (through fairer trade of shea products), accelerated land conversion (through protection and restoration of degraded lands) and decrease of environmental suitability (through climate change adaptation to restore and maintain biotic and abiotic systems supporting shea habitat), is predicted as the most likely to succeed at enhancing shea conservation and its provision of NCP to people.

The BBN developed here used a qualitative approach based on experts' criteria, since the lack of quantitative data on this system prevented the development of a more precise quantitative representation. 
While the current approach can provide valuable insights and can constructively inform the discussion on alternative policy actions and their potential to influence the shea tree system, we emphasize the need to gather and systematize comprehensive, quantitative data to develop more sophisticated models to further our knowledge on this system in the future.

\section{Conclusion}

This study highlights the efficacy of a social-ecological modelling approach in shea tree management. Indeed, the conceptual model based on social-ecological drivers of change in shea tree abundance, enables deeper understanding of the relationship between these drivers and their effects on shea tree dynamics. The development of the four scenarios provided insight into the suitability of different policy options to improve shea tree management in the future. From this study, we conclude that the policy options enabled in the "conservation and fair trade scenario" might have most positive effects on shea tree abundance and local provision of NCP. Overall, we can highlight three main points from this study. First, we demonstrate that framing a case study at a local scale by identifying principal components and subsequently developing a conceptual model can be a useful exercise in identifying opportunities for effective policy strategies and social innovation. Such an approach can further guide IPBES in capturing the social-ecological dynamics of biodiversity and NCP at varying scales. Second, through the development of a conceptual model, and identifying key processes and products as NCP, we were able to generate a better understanding of potential policy options, which consequently allowed us to develop possible socio-ecological scenarios. Third, modelling scenarios can be a powerful tool to communicate with society more broadly, to raise awareness of current situations and potential futures, and to better explain the necessary interventions for a more sustainable future.

The model and workflow applied here may thus be used to understand similar socio-ecological systems with local and international economic value across the Neotropical region (Guariguata et al. 2017) in order to assess the qualitative potential future outcomes of the scenarios proposed, and could be useful to inform policy decisions for the sustainable management. We would like to stress that the presented alternative states represent broad generalisations of possible outcomes for the system. Before application of this model in practice, casespecific system states should be identified in collaboration with local stakeholders using appropriate social science techniques.

\section{Supplementary material:}

The following online material is available for this article:

Figure S1 - Bayesian Belief Network model structure of the "conservation and fair trade" scenario. Nodes in the upper row represent policies, whereas nodes in the second row represent pressures. The probability distributions of policy nodes reflect the estimated current implementation of each policy.

Figure S2 - Bayesian Belief Network model structure of the "agroforestry and fair trade" scenario. Nodes in the upper row represent policies, whereas nodes in the second row represent pressures. The probability distributions of policy nodes reflect the estimated current implementation of each policy.
Figure S3 - Bayesian Belief Network model structure of the "industrial development" scenario. Nodes in the upper row represent policies, whereas nodes in the second row represent pressures. The probability distributions of policy nodes reflect the estimated current implementation of each policy.

Iable SI - Overexploitation.

Table S2 - Erosion of climate and soil.

Tahle S3 - Erosion of biotic interactions.

Tahle S4 - Land use change (LUC).

Table S5 - Shea tree abundance.

Iable S6 - Current policy.

Tahle S7 - Potential indicators for Nature's Contributions to People in the conceptual model of the shea tree social-ecological system.

\section{Acknowledgements}

The authors would like to thank the Fundação de Amparo à Pesquisa do Estado de São Paulo (FAPESP) and all organisers and speakers at the Sao Paulo School of Advanced Science on Scenarios and Modelling on Biodiversity and Ecosystem Services to Support Human Well-Being (SPSAS scenarios), for creating an open collaborative space to share advanced knowledge and modelling practice. We thank Janeth Lessmann for her insightful comments and feedback on the model and Bayesian Belief Network. B.L and J.F. are grateful to FAPESP for supporting their participation in the School. J.M.A. is supported by a United Kingdom Natural Environment Research Council (NERC) Doctoral Training Partnership (DTP) studentship [grant number: NE/L002485/1]. J.C.A. and E.W.A.W. were financed in part by the Coordenação de Aperfeiçoamento de Pessoal de Nível Superior - Brasil (CAPES) - Finance Code 001 and FAPESP. E.C.G. was financed through the Consejo Nacional de Ciencia y Tecnología (CONACYT) doctoral scholarship 291137, project 249781 PROINPEP (2019) from CUCOSTA-UdeG and FAPESP. A.M.B was financed through the Consejo Nacional de Ciencia y Tecnología (CONACYT) doctoral scholarship 579646 and FAPESP. E.A.N-U. is grateful to the Instituto Alexander von Humboldt for the support received to participate in the SPSAS scenarios (Sao Pedro- Brazil, 2019).

\section{Author Contributions}

Loyapin Bondé: contributed equally to the concept and design of the study, and manuscript preparation; performed critical review and revisions;

Julia Camara Assis: contributed equally to the concept and design of the study, and manuscript preparation; performed critical review and revisions;

Sandra Benavides-Gordillo: contributed equally to the concept and design of the study, and manuscript preparation;

Erendira Canales-Gomez: contributed equally to the concept and design of the study, and manuscript preparation;

Javier Fajardo: contributed equally to the concept and design of the study, and manuscript preparation; performed analysis and interpretation of Bayesian Belief Networks.

Aurora Marrón-Becerra: contributed equally to the concept and design of the study, and manuscript preparation; 
Elkin A. Noguera-Urbano: contributed equally to the concept and design of the study, and manuscript preparation;

Emanuela W. A. Weidlich: contributed equally to the concept and design of the study, and manuscript preparation; performed critical review and revisions;

Judith M. Ament: contributed equally to the concept and design of the study, and manuscript preparation; performed critical review and revisions; coordinated the manuscript preparation and prepared the final manuscript for submission.

\section{Conflicts of interest}

The authors declare that they have no conflict of interest related to the publication of this manuscript.

\section{Ethics}

The authors declare that the analysis detailed in this manuscript did not involve human beings and/or clinical trials.

\section{Data availability}

The authors declare that the analysis detailed in this manuscript involved conceptual models only. No data was used in the analysis.

\section{References}

ABDULRAHAMAN, A. A., FAJEMIROYE, O.J. \& OLADELE F.A. 2006. Ethnobotanical study of economic trees: uses of trees as timbers and fuelwoods in Ilorin Emirate of Kwara State, Nigeria. Ethnobotanical Leafles, 10:113-120.

ABSON, D.J., FISCHER, J., LEVENTON, J., NEWIG, J., SCHOMERUS, T., VILSMAIER, U., VON WEHRDEN, H., ABERNETHY, P., IVES, C.D., JAGER, N.W. \& LANG, D.J. 2017. Leverage points for sustainability transformation. Ambio 46(1):30-39.

ALEZA, K., VILLAMOR, G.B., NYARKO, B.K., WALA, K. \& AKPAGANA, K. 2018. Shea (Vitellaria paradoxa Gaertn C.F.) fruit yield assessment and management by farm households in the Atacora district of Benin. PLOS One 13(1): e0190234. https://doi.org/10.1371/journal.pone.0190234

APFNL-Agence des Produits Forestiers Non Ligneux. 2012. Stratégie nationale de valorisation et de promotion des produits forestiers non ligneux. Agence des Produits Forestiers Non Ligneux. Ministere de l'Environnement Burkina Faso et du Cadre de Vie, Ouagadougou, Burkina Faso. 34p. http://www.fao. org/3/ap866f/ap866f00.pdf.

BARGUÉS-TOBELLA, A, HASSELQUIST, NJ, BAZIÉ, HR, BAYALA, J, LAUDON, H \& ILSTEDT, U. 2019. Trees in African drylands can promote deep soil and groundwater recharge in a future climate with more intense rainfall. Land Degradation and Development. 1-15.

BAYALA, J., BALESDENT, J., MAROL, C., ZAPATA, F., TEKLEHAIMANOT, Z. \& OUEDRAOGO, S. 2006. Relative contribution of trees and crops to soil carbon content in a parkland system in Burkina Faso using variations in natural $13 \mathrm{C}$ abundance. Nutrient Cycling in Agroecosystems, 76 (2-3):193-201.

BELCHER, B. M., RUIZ-PEREZ, M. \& ACHDIAWAN, R.A. 2005. Global patterns and trends in the use and management of commercial NTFPs: implications for livelihoods and conservation. World Development 33 (9): 1435-1452. doi:10.1016/j.worlddev.2004.10.007

BERTWELL, T. D., KAINER, K.A., CROOPER JR., W.P., STAUDHAMMER, C.L. \& DE OLIVEIRA WADT, L.H. 2018. Are Brazil nut populations threatened by fruit harvest?. Biotropica 59(1): 50-59. https://doi. org/10.1111/btp. 12505
BOFFA, J.M. 2015. Opportunities and challenges in the improvement of the shea (Vitellaria paradoxa) resource and its management. Occasional Paper 24. Nairobi: World Agroforestry Centre.

BONDÉ, L., OUÉDRAOGO, O., OUÉDRAOGO, I., THIOMBIANO, A. \& BOUSSIM, J. I. 2019a. Variability and estimating in fruiting of shea tree (Vitellaria paradoxa C.F. Gaertn) associated to climatic conditions in West Africa: implications for sustainable management and development. Plant Production Science 22(2):143-158.

BONDÉ L., OUÉDRAOGO O., TRAORÉ S., THIOMBIANO A. \& BOUSSIM I.J, 2019b. Impact of environmental conditions on fruit production patterns of shea tree (Vitellaria paradoxan C.F.Gaertn) in West Africa. African Journal of Ecology. 57:3, 353-362. https://doi.org/10.1111/aje.1262

BOOTH, F. E. \& WICKENS G. E. 1988. Non-timber uses of selected arid zone trees and shrubs in Africa. Food \& Agriculture Org. Rome.

BOUSSIM, J., SALLÉ, G. \& GUINKO, S. 1993. Tapinanthus parasite du Karité au Burkina Faso. 1ère partie identification et distribution. Bois \& forets des tropiques, 238(238):45-52.

BROOK, B. W., SODHI, N. S. \& BRADSHAW, C. J. 2008. Synergies among extinction drivers under global change. Trends in ecology \& evolution, 23(8):453-460.

BUP, D. N., MOHAGIR, A. M., KAPSEU, C. \& MOULOUNGUI, Z. 2014. Production zones and systems, markets, benefits and constraints of shea (Vitellaria paradoxa Gaertn) butter processing. Oilseeds Fats Crops Lipids 21:D206.

CEBALLOS, G., EHRLICH, P. R., BARNOSKY, A. D., GARCÍA, A., PRINGLE, R. M. \& PALMER, T. M. 2015. Accelerated modern human-induced species losses: Entering the sixth mass extinction. Science advances, 1(5):e1400253.

CISSÉ M., BATIONO B. A., TRAORÉ S. \& BOUSSIM I. J. 2018. Perception d'espèces agroforestières et de leurs services écosystémiques par trois groupes ethniques du bassin versant de Boura, zone soudanienne du Burkina Faso.Bois et Forêts des Tropiques 338:29-42.

CHEVALIER, A. 1946. L'arbre à beurre d'Afrique et l'avenir de sa culture. Oléagineux 1: 7-11

COHEN-SHACHAM, E.,WALTERS, G., JANZEN, C. \& MAGINNIS, S. 2016. Nature-based solutions to address global societal challenges. IUCN: Gland, Switzerland, 97.

DAYAMBA, S.D., DJOUDI, H., ZIDA, M., SAWADOGO, L. \& VERCHOT, L. 2016. Biodiversity and carbon stocks in different land use types in the Sudanian Zone of Burkina Faso, West Africa. Agriculture, Ecosystems \& Environment 216:61-72.

DAPILAH, F., NIELSEN, J.Ø. \& AKONGBANGRE, J.N. 2018. Peri-urban transformation and shared natural resources: the case of shea trees depletion and livelihood in Wa municipality, Northwestern Ghana. African Geographical Review, 1-16.

DIARASSOUBA, N., KOFFI, K., N'GUESSAN, K., DAMME, P. \& SANGARE, A. 2008. Connaissances locales et leur utilisation dans la gestion des parcs à Karité en Côte d'Ivoire. Afrika Focus 21: 77-96

DÍAZ, S., DEMISSEW, S., CARABIAS, J., JOLY, C., LONSDALE, M., ASH, N., LARIGAUDERIE, A., ADHIKARI, J.R.,ARICO, S., BÁLDI,A., BARTUSKA, A., BASTE, I.A., BILGIN, A., BRONDIZIO, E., CHAN, K.M.A., FIGUERO, A.V.E., DURAIAPPAH, A., FISCHER, M., HILL, R., KOETZ, T., LEADLEY, P., LYVER, P., MACE, G.M., MARTIN-LOPEZ, B., OKUMURA, M., PACHECO, D., PASCUAL, U., PÉREZ, E.S., REYERS, B., ROTH, E., SAITO, O., SCHOLES, R.J., SHARMA, N., TALLIS, H., THAMAN, R., WATSON, R., YAHARA, T., HAMID, Z.A., AKOSIM, C., ALHAFEDH, Y., ALLAHVERDIYEV, R.,AMANKWAH, E.,ASAH, S.T., ASFAW,Z., BARTUS, G., BROOKS, L.A., CAILLAUX, J., DALLE, G., DARNAEDI, D., DRIVER, A., ERPU, G., ESCOBAR-EYZAGUIRRE, P., FAILLER, P., FOUDA, A.M.M., FU, B., GUNDIMEDA, H., HASHIMOTO, S., HOMER, F., LAVOREL, S., LICHTENSTEIN, G., MALA, W.A., MANDIVENYI, W., MATCZAK, P., MBIZVO, C., MEHRDADI, M., METZGER, JP., MIKISSA, J.B., MOLLER, H., MOONEY, H.A., MUMBY, P., NAGENDRA, H., NESSHOVER, C., OTENGYEBOAH, A.A., PATAKI, G., ROUÉ, M., RUBIS, J., SCHULTZ, M., SMITH, P., SUMAILA, R., TAKEUCHI, K., THOMAS, S., VERMA, M., YEOCHANG, Y., \& ZLATANOVA, D. 2015. The IPBES conceptual framework — connecting nature and people. Curr Opin Environ Sustain 14:1-16. 
DÍAZ, S., PASCUAL, U., STENSEKE, M., MARTÍN-LÓPEZ, B., WATSON, R.T., MOLNÁR, Z., HILL, R., CHAN, K.M.A., BASTE, I.A., BRAUMAN, K.A., POLASKY, S., CHURCH, A., LONSDALE, M., LARIGAUDERIE, A., LEADLEY, P.W., VAN OUDENHOVEN, A.P.E., VAN DER PLAAT, F., SCHRÖTER, M., LAVOREL, S., AUMEERUDDY-THOMAS, Y., BUKVAREVA, E., DAVIES, K., DEMISSEW, S., ERPUL, G., FAILLER, P., GUERRA, C.A., HEWITT, C.L., KEUNE, H., LINDLEY, S. \& SHIRAYAMA, Y. 2018 Assessing nature's contributions to people. Science 359(6373): 270.

DIMOBE, K., KUYAH, S., DABRÉ, Z., OUÉDRAOGO, A. \& THIOMBIANO, A. 2019. Diversity-carbon stock relationship across vegetation types in $W$ National park in Burkina Faso. Forest Ecology and Management 438:243-254.

DJOSSA, B. A., FAHR, J., KALKO, E. K. V. \& SINSIN, B. A. 2008. Fruit selection and effects of seed handling by flying foxes on germination rates of shea trees, a key resource in northern Benin, West Africa. Ecotropica (Bonn), 14(1):37-48.

ELIAS, M. 2012. Influence of agroforestry practices on the structure and specialty of shea trees (Vitellaria paradoxa C.F. Gaertn.) in central-west Burkina Faso. Agroforestry Systems 87: 203-216. DOI 10.1007/s10457-012-9536-2

ELIAS, M. 2015. Gender, knowledge-sharing and management of shea (Vitellaria paradoxa) parklands in central-west Burkina Faso. Journal of rural studies 38: 27-28.

ELIAS, M. , BAYALA, J. \& DIANDA, M. 2006. Impediments and innovations in knowledge sharing: the case of the African Vitellaria paradoxa sector. Knowledge Management for Development Journal 2(1): 52-67.

ELIAS, M. \& CARNEY, J. 2007. African Shea Butter: A Feminized Subsidy from Nature. Africa: Journal of the International African Institute 77(1):37-62.

EVANS, T. E. 1996. The effects of changes in the world hydrological cycle on the availability of water resources, in Bazzaz, F. and Sombroek, W. (eds.), Global Climate Change and Agricultural Production, Wiley, Chichester, p. 248

GAISBERGER, H., KINDT, R., LOO, J., SCHMIDT, M., BOGNOUNOU, F., D.A., S. S. \& VINCETI, B. 2017. Spatially explicit multi-threat assessment of food tree species in Burkina Faso: A fine-scale approach. PLOS ONE, 12, e0184457.

GLELE, R., AKPONA, T.J.D., ASSOGBADJO, A.E., GAOUE, O.G., CHAKEREDZA, S., GNANGLE, P.C., MANSAH, G.A. \& SINSIN, B. 2011. Ecological adaptation of the shea butter tree (Vitellaria paradoxa C.F. Gaertn.) along climatic gradient in Bénin, West Africa. Afrikan Journal of Ecology 49(4): 440-449. https://doi.org/10.1111/j.1365-2028.2011.01279.x

GODIN, V J. \& SPENSLEY, P. C. 1971. Oils and oilseeds. [London] Tropical Products Institute, Foreign and Commonwealth Office (Overseas Development Administration.

GREIG, D. 2006. Shea butter: connecting rural Burkinabè women to international markets through fair trade, Development in Practice, 16(5):465-475

GUARIGUATA, M. R., CRONKLETON, P., DUCHELLE, A.E. \& ZUIDEMA, P.A. 2017. Revisiting the 'cornerstone of Amazonian conservation': a socioecological assessment of Brazil nut exploitation. Biodiversity and Conservation 26(9): 2007-2027. DOI: 10.1007/s10531-017-1355-3.

GWALI, S., OKULLO, J. B. L., EILU, G., NAKABONGE, G., NYEKO, P. \& VUZI, P. 2012. Traditional management and conservation of shea trees (Vitellaria paradoxa subspecies nilotica) in Uganda. Environment, development and sustainability, 14(3):347-363.

HALL J.B., AEBISCHER P.D., TOMLINSON H.F., OSEI-AMANING E. \& HINDLE J.R. 1996. Vitellaria paradoxa: a monograph (p. 105). Bangor, UK: School of Agricultural and Forest Sciences, University of Wales.

HATSKEVICH, A., JENICEK V. \& DARKWAH, S. A .2011. Shea industry. A means of poverty reduction in Northern Ghana. Agricultura Tropica et Subtropica 44:223-228.

HOUEHANOU, T.D., KINDOMIHOU, V. \& SINSIN, B.A. 2011. Effectiveness of conservation areas in protecting Shea trees against hemiparasitic plants (Loranthaceae) in Benin, West Africa. Plant Ecology and Evolution, 144(3):267-274.

ILSTEDT, U., BARGUÉS TOBELLA, A., BAZIÉ, H.R., BAYALA, J., VERBEETEN, E., NYBERG, G., SANOU, J., BENEGAS, L., MURDIYARSO, D., LAUDON, H., SHEIL, D. \& MALMER, A. 2016. Intermediate tree cover can maximize groundwater recharge in the seasonally dry tropics. Scientific Reports 6:21930.
IPBES. 2016. The Methodological Assessment Report on Scenarios and Models of Biodiversity and Ecosystem Services. Edited by S Ferrier, K N Ninan, P Leadley, R Alkemade, L A Acosta, H R Akcakaya, L Brotons, et al. Bonn, Germany: Secretariat of the Intergovernmental Science-Policy Platform on Biodiversity and Ecosystem Services.

IUCN 1998. Makerere University Institute of Environment And Natural Resources. Vitellaria paradoxa. The IUCN Red List of Threatened Species 1998: e.T37083A10029534. http://dx.doi.org/10.2305/IUCN.UK.1998. RLTS.T37083A10029534.en. (last access in 13/10/2019).

INGRAM, V., YAGO-OUATTARA, E., LARTTEY, A., MOGRE, D., WIJNANDS, J. \& VAN DER BERG, J. 2015. Gender dynamics in cashew and shea value chains from Ghana and Burkina Faso. LEI Report 2015-039. Wageningen University and Research center. $60 \mathrm{pp}$.

JENSEN, F.V. 2001. Bayesian Networks and Decision Graphs. Springer, New York.

KOK, M. T., KOK, K., PETERSON, G. D., HILL, R., AGARD, J. \& CARPENTER, S. R. 2017. Biodiversity and ecosystem services require IPBES to take novel approach to scenarios. Sustainability Science, 12(1):177-181.

KUWABONG, D. 2004. Bagre: a Dagaaba celebration of environmental balance between humans and non-humans. J Dagaare Stud. 4:1-13.

LAMIEN, N., TIGABU, M., DABIRE, R., GUINKO, S. \& ODEN, P.C. 2008. Insect (Salebria sp.) infestation and impact on Vitellaria paradoxa C.F. Gaertn. Fruit production in agroforestry parklands. Agroforestry Systems 72: $15-22$.

LANGMEAD, O., MCQUATTERS-GOLLOP, A., MEE, L. D., FRIEDRICH, J., GILBERT, A. J., GOMOIU, M. T., JACKSON, E. L., KNUDSEN, S., MINICHEVA, G. \& TODOROVA, V. 2009. Recovery or decline of the northwestern Black Sea: A societal choice revealed by socio-ecological modelling. Ecological Modelling, 220(21):2927-2939.

LAUTITZEN, 1. \& SPIEGELHALTER D.J. 1988. Local computations with probabilities on graphical structures and their application on expert systems. Journal of the Royal Statistical Society B 50 (2): 157-224.

LIU, J., MOONEY, H., HULL, V., DAVIS, S.J., GASKELL, J., HERTEL, T., LUBCHENCHO, J., SETO, K.C., GLEICK, P. \& KREMEN, C. 2015. Systems integration for global sustainability. Science. 347:1258832.

MAANIKUU, P. M. I. \& PEKER, K. 2017. Medicinal and Nutritional Benefits from the Shea Tree (Vitellaria paradoxa). Journal of Biology Agriculture and Healthcare, 7(22):51-57.

MORRIS, R. J. 2010. Anthropogenic impacts on tropical forest biodiversity: a network structure and ecosystem functioning perspective. Philosophical Transactions of the Royal Society B: Biological Sciences. 365(1558):3709-3718.

NACOULMA, B. M. I., SCHUMANN, K., TRAORE, S., BERNHARDTROMERMANN, M., HAHN-HADJALI, K., WITTIG, R. \& THIOMBIANO A., 2011. Impacts of land-use on West African savanna vegetation: a comparison between protected and communal area in Burkina Faso. Biodiversity and Conservation, 20 (14): 3341-3362.

NAUGHTON, C.C., LOVETT, P.N. \& MIHELCIC, J.R. 2015. Land suitability modeling of shea (Vitellaria paradoxa) distribution across sub-Saharan Africa. Applied Geography 58:217-227.

N'DJOLOSSÈ, K., ATACHI, P. \& GNANGLÈ, C. 2012. Inventory of insects associated with shea trees (Vitellaria paradoxa) (Sapotaceae) in central and northern Benin. International Journal of Tropical Insect Science, 32(3):158-165.

NIKIEMA, A., VAN DER MAESEN, L.J.G. \& HALL, J.B. 2003. The impact of parkland management practices on plant resources diversity. pp 43-50. In Improved management of agroforestry parklands systems in SubSaharan Africa. EU/INCO Project contract IC18CT98-0261. Final Report. (Teklehaimanot, Z. ed) University of Wales Bangor, UK.

NOMA, F., HOUESSIONON, P. \& YABI, J.A. 2019. The Effects of Climate Change Adaptation Strategies on Shea-Parks Conservation in Northern Benin, West-Africa. In Advancing Climate Change Research in West Africa: Trends, Impacts, Vulnerability, Resilience, Adaptation and Sustainability Issues. (S. E. H. Kokoye, R. N. Yegbemey \& O. H. R. Awoye, eds). Nova Science Publisher, New York. 
OKIROR, P., AGEA, J.G., OKIA, C.A. \& OKULLO, J.B.L. 2012. On-farm management of Vitellaria paradoxa CF Gaertn. In Amuria District, Eastern Uganda. International Journal of Forestry Research.

OKULLO, J. B. L., HALL, J.B. \& ELIOT, M. 2003. Reproductive biology and breeding systems of Vitellaria paradoxa. pp. 66-84. In INCO: International Scientific Cooperation Projects 1998-2002: Improved Management of agroforestry parklands systems in Sub Sharan Africa. Final report. (Teklehaimanot, Z. ed) School of Agricultural and Forest Sciences, Bangor, UK.

ONTL, K.M.B. 2017. Chimpanzees in the Island of Gold: Impacts of artisanal small-scale gold mining on chimpanzees (Pan troglodytes verus) in Fongoli, Senegal.

OUEDRAOGO, I. , TIGABU, M., SAVADOGO, P., COMPAORE, H., ODEN, P.C. \& OUADBA, J.M. 2010. Land cover change and its relation with population dynamics in Burkina Faso, West Africa. Land Degradation \& Development. 21(5): 453 462. https://doi.org/10.1002/ldr.981

PETRE, C. A., TAGG, N., HAUREZ, B., BEUDELS-JAMAR, R., HUYNEN, M.C. \& DOUCET, J.L. 2013. Role of the western lowland gorilla (Gorilla gorilla gorilla) in seed dispersal in tropical forest and implications of its decline. Biotechnology, Agronomy, Society and Environment 17(3): 517-526.

PLATTS, P. J., POUDYAL, M. \& MCCLEAN, C. J. 2010. Modeling shea under climate scenarios. Report for INNOVKAR Work Package 2. UK: University of York.

PORCHER, V., THOMAS, E., CORVERA-GOMRINGER, R. \& BARDALESLOZANO, L. 2018. Fire and distance dependent recruitment of the Brazil nut in the Peruvian Amazon. Forest Ecology and Management 427: 52-59.

POTTS, S. G., BIESMEJIER, J. C., KREMEN, C., NEUMANN, P., SCHWEIGER, O. \& KUNIN, W. E. 2010. Global pollinator declines: trends, impacts and drivers. Trends in ecology \& evolution, 25(6), 345-353.

POUDYAL, M. 2011. Chiefs and Trees: Tenures and Incentives in the Management and Use of Two Multipurpose Tree Species in Agroforestry Parklands in Northern Ghana. Society \& Natural Resources 24(10):1063-1077.

POULIOT, M. 2012. Contribution of "women's gold" to West African livelihoods: The case of shea in Burkina Faso. Economic Botany. 66(3): 237-248. doi:10.1007/s12231-012-9203-6

RÆBILD, A., HANSEN, U. B. \& KAMBOU, S. 2012. Regeneration of Vitellaria paradoxa and Parkia biglobosa in a parkland in Southern Burkina Faso. Agroforestry Systems 85:443-453.

RATTO, F., SIMMONS, B.I., SPAKE, R., ZAMORA-GUTIERREZ, V. MACDONALD, M.A., MERRIMAN, J.C., TREMLETT, C.J., POPPY, G.M., PEH, K.S.H. \& DICKS, L.V. 2018. Global importance of vertebrate pollinators for plant reproductive success: a meta-analysis. Frontiers in Ecology and the Environment 16(2): 82-90. doi: 10.1002/fee.1763

ROUSSEAU, K., GAUTIER, D. \& WARDELL, D.A. 2015. Coping with the upheavals of globalization in the sea value chain: the maintenance and relevance of upstream sea nut supply chain organization in Western Burkina Faso. World Development 66: 413-427. http://dx.doi.org/10.1016/j. worlddev.2014.09.004
SANOGO, K., GEBREKIRSTOS, A., BAYALA, J., VILLAMOR, G. B., KALINGANiRE, A. \& DODIOMON, S. 2016. Potential of dendrochronology in assessing carbon sequestration rates of Vitellaria paradoxa in southern Mali, West Africa. Dendrochronologia 40:26-35.

SARDAR, Z. \& SWEENEY, J. A. 2016. The Three Tomorrows of Postnormal Times. Futures, 75:1-13.

SEGHIERI, J. 2019. Shea tree (Vitellaria paradoxa Gaertn. f.): from local constraints to multi-scale improvement of economic, agronomic and environmental performance in an endemic Sudanian multipurpose agroforestry species. Agroforestry Systems, 1-18.

SERPANTIE, G., BAYALA, J., HELMFRID, S. \& LAMIEN, N. 1996. Pratiques et enjeux de la culture du karite' (Butyrospermum paradoxum Gaertn. f.Hepper) dans l'Ouest du Burkina Faso. In The workshop proceedings on La jache're, lieu de production, Bobo Dioulasso, Burkina Faso (C. Floret, ed) $\mathrm{p}$ 59-72.

SHACKLETON, C. M. \& R. J. SCHOLES. 2011. Above ground Woody community attributes, biomass and carbon stocks along a rainfall gradient in the savannas of the central Lowveld, South Africa. South African Journal of Botany 77(1): 184-192.

STOUT, J., NOMBRE, I., DE BRUIJN, B., DELANEY, A., DOKE, D., GYIMAH, T., KAMANO, F., KELLY, R., LOVETT, P., MARSHALL, E., NASARE, L., NANA, A., ROBERTS, J., TANKOANO, P., TAYLEUR, C., THOMAS, D., VICKERY, J. \& KWAPONG, P. 2018. Insect pollination improves yield of Shea (Vitellaria paradoxa subsp. paradoxa) in the agroforestry parklands of West Africa. Journal of Pollination Ecology, 22:11-20.

TEKLEHAIMANOT, Z. 2004. Exploiting the potential of indigenous agroforestry trees: Parkia biglobosa and Vitellaria paradoxa in sub-Saharan Africa. Agrofor Syst 61:207-220.

VAN NOORDWIJK, M., BAYALA, J., HAIRIAH, K., LUSIANA, B., MUTHURI, C., KHASANAH, N. \& MULIA, R. 2014. Agroforestry solutions for buffering climate variability and adapting to change. In Climate change impact and adaptation in agricultural systems, Chap. 16 (J. Fuhrer \& P. J. Gregory, eds), p. 216-232.

VOHLAND, K., MLAMBO, M. C., HORTA, L. D., JONSSON, B., PAULSCH, A. \& MARTINEZ, S. I. 2011. How to ensure a credible and efficient IPBES? Environ. Sci. Policy. 14(8):1188-1194.

WEZEL, A. \& A. M. LYKKE. 2006. Woody vegetation change in Sahelian West Africa: evidence from local knowledge. Environment, Development and Sustainability 8: 553-567.

WITTIG, R., KONIG, K., SCHMID, T. M. \& SZARZYNSKI J., 2007. A Study of Climate Change and Anthropogenic Impact in West Africa. Environmental Science and Pollution Research, 14 (3): 182-189. doi: http://dx.doi. org/10.1065/espr2007.02.388. 